TITLE:

\title{
ANATOMICAL REVIEW OF SUBCUTHONA PALLIDA BABA (NUDIBRANCHIA-EOLIDACEA)
}

$\operatorname{AUTHOR}(\mathrm{S})$ :

Baba, Kikutaro

\section{CITATION:}

Baba, Kikutaro. ANATOMICAL REVIEW OF SUBCUTHONA PALLIDA BABA (NUDIBRANCHIAEOLIDACEA). PUBLICATIONS OF THE SETO MARINE BIOLOGICAL LABORATORY 1962,

10(2): $241-243$

ISSUE DATE:

1962-12-31

URL:

http://hdl.handle.net/2433/175312

RIGHT: 


\title{
ANATOMICAL REVIEW OF SUBCUTHONA PALLIDA BABA (NUDIBRANCHIA - EOLIDACEA)
}

\author{
KikUTARÓ BABA \\ Biological Laboratory, Osaka Gakugei University, Osaka
}

With Plate $X V$

Since the appearance of the first record of Subcuthona pallida BABA, 1949 (pp. 100-101, 176, pl. 42, figs. 147-148, text-fig. 130) from Sagami Bay, Pacific coast of Japan, additional collections of the specimens of the same form have been made on the side of the Sea of Japan as below:

1. Near the Sado Marine Biological Station, Sado I. (Aug. 1954, 2 sps.).

2. Abugashima, Toyama Bay (Aug. 1953, 4 sps.).

The slugs, matured, measure about $2 \mathrm{~mm}$ in length in the living state. The general body-colour is pure white with pale yellow liver system shining through the transparent skin as in the type. The cephalic tentacles are finely dotted with opaque white. The rhinophores are faintly yellowish.

The general body-form is also as in the type: the right liver (and the left partner) has 3 (rarely 4) branches, each containing a single papilla. The genital orifice lies below the 2nd papilla on the right side; the acleioproctic anus opens in front of the 1st right papilla of the posterior liver; the nephroproct is closely preanal. The branchial papillae themselves are varying in size, easily falling off, and elongated fusiform with an apical cnidosac in each.

Internally, the pharynx is provided with a pair of simple salivary glands. The oral glands (=ptyaline glands) are short, and thick. The jaw-edge has a row of about 30 denticles. The radula formula in one specimen is $40 \times 0.1 .0$; the median cusp of the central tooth is as large as the lateral (4) denticles. The digestive tract (oesophagus, stomach and intestine) is lined as usual with a low ciliated epithelium. As for the liver system, it is wholly glandular in nature. The kidney is a simply elongated sac without branching. The reno-pericardial canal is also simple (wall not folded). There are only 4 testes; each one is accompanied by (3) ovaries. The penis is muscular; it is short, obtusely conical and armed with an apical stylet. The vas deferens consists of a muscular part and a prostatic portion. A penis gland is present.

Publ. Seto Mar. Biol. Lab., X (2), 1962. (Article 12) 
As may readily be seen from the foregoing accounts and the annexed figures, the genus Subcuthona is closely related to Catriona (or Trinchesia of PRUvot-Fol, 1951, p. 64) and Cuthona in having 3 branches in the right liver (and the left partner) ; further, it has a penis stylet in common with Catriona. But Subcuthona deviates from Catriona in the extremely reduced number of papillae in each of the liver branches (for the simplification tendency of the liver branches, see Odhner, 1939, p. 51). Subcuthona may not intimately be linked with Tergipes and Embletonia; these latter have different types of the liver system and genitalia from the former (see also Marcus, 1959, p. 920).

A revised characterization of the genus Subcuthona BABA, 1949 (pp. 100, 176) follows thus:

Cuthonidae. Related especially to Catriona (or Trinchesia of PRUVOT-FoL, 1951), but the branchial papillae are in a single longitudinal row on each backmargin. Other characters are generally as in Catriona: the rhinophores simple, the foot-corners rounded, the right liver (and the left partner) with $3(-4)$ branches, the acleioproctic anus in the interhepatic space, the nephroproct closely preanal. Jaw-edge with a row of denticles. Radula formula 0.1 .0 ; median cusp of the central tooth approximately as large as the lateral denticles. Penis short, obtusely conical, armed with an apical stylet; part of vas deferens forming a prostata; with a penis gland.

My thanks are due to Dr. Yoshiharu Honma (Department of Biology, Niigata University) and Mr. Takeo ABE (Takaoka High School, Toyama Pref.) by whom I was able to have specimens for dissection here.

\section{REFERENCES}

BABA, K. 1949. Opisthobranchia of Sagami Bay. Iwanami Shoten, Tokyo.

MACNAE, W. 1954 a. On some eolidacean nudibranchiate molluses from South Africa. Ann. Natal Mus., vol. 13, pt. 1.

1954b. On the status of the generic names of the nudibranch genera Catriona,

Cratena, Hervia, Rizzolia and Trinchesia. Proc. Malac. Soc. London, vol. 31, no. 2.

Marcus, Er. \& Ev. 1959. Opisthobranchia aus dem Roten Meer und von den Malediven. Abh. math.-naturwiss. Kl., Jg. 1959, No. 12.

ODHNER. N. 1939. Opisthobranchiate Mollusca from the western and northern coasts of Norway. Kgl. Norske Vidensk. Selskab. Skr., no. 1.

Pruvot-Fol, A. 1951. Etude des nudibranches de la Méditerranée. Arch. Zool. Exp. et Gén., tom. 88 , fasc. 1 .

1) After MACNAE, 1954 a, pp. 3-4 ; 1954 b, pp. 52-53 ; MARCus, 1959, pp. 917-918, and others. 


\section{EXPLANATION OF PLATE XV}

Figs. 1-10, Subcuthona pallida from Sado I. (Aug. 2, 1954);

Figs. 11-12, the same species from Toyama Bay (Aug. 8, 1953).

Fig. 1. Entire animal in life (length $2 \mathrm{~mm}$ ).

Fig. 2. Internal anatomy, diagrammatic. a. salivary gland, b. right liver branches, c. genital orifice, d. nephroproct, e. anus, f. kidney, g. posterior liver branches, $h$. left liver branches, i. stomach, j. oral gland. The glandular part of the liver system is thickly dotted with black; an inner longitudinal ridge is shown in the proximal half of the intestine.

Fig. 3. A salivary gland.

Fig. 4. An oral gland.

Fig. 5. A branchial papilla. a. special cells, b. liver diverticulum, c. cnidosac.

Fig. 6. Proximal constriction of the liver diverticulum. a. septum, b. muscular ring.

Fig. 7. Cnidocysts $(\times 300)$, a. outer muscular layer of the cnidosac, b. cnidocyst, c. nematocyst.

Fig. 8. Central nervous system. a. cerebro-pleural ganglion, b. pedal ganglion.

Fig. 9. Kidney. a. reno-pericardial canal, b. nephroproct.

Fig. 10. Genital system, diagrammatic. a. penis gland, b. muscular part of vas deferens, c. prostatic part of the same, d. penis, e. stylet, f. genital orifice, g. outer oviduct, h. spermatheca, i. albumen gland, j. hermaphrodite duct, k. ovary, l. testis, m. ampulla, n. mucous gland.

Fig. 11. Denticulation of the jaw-edge $(\times 600)$.

Fig. 12. A central tooth $(\times 700)$. 
Publ. Seto Mar. Biol. Lab., X, 2 (1962)

PLATE XV

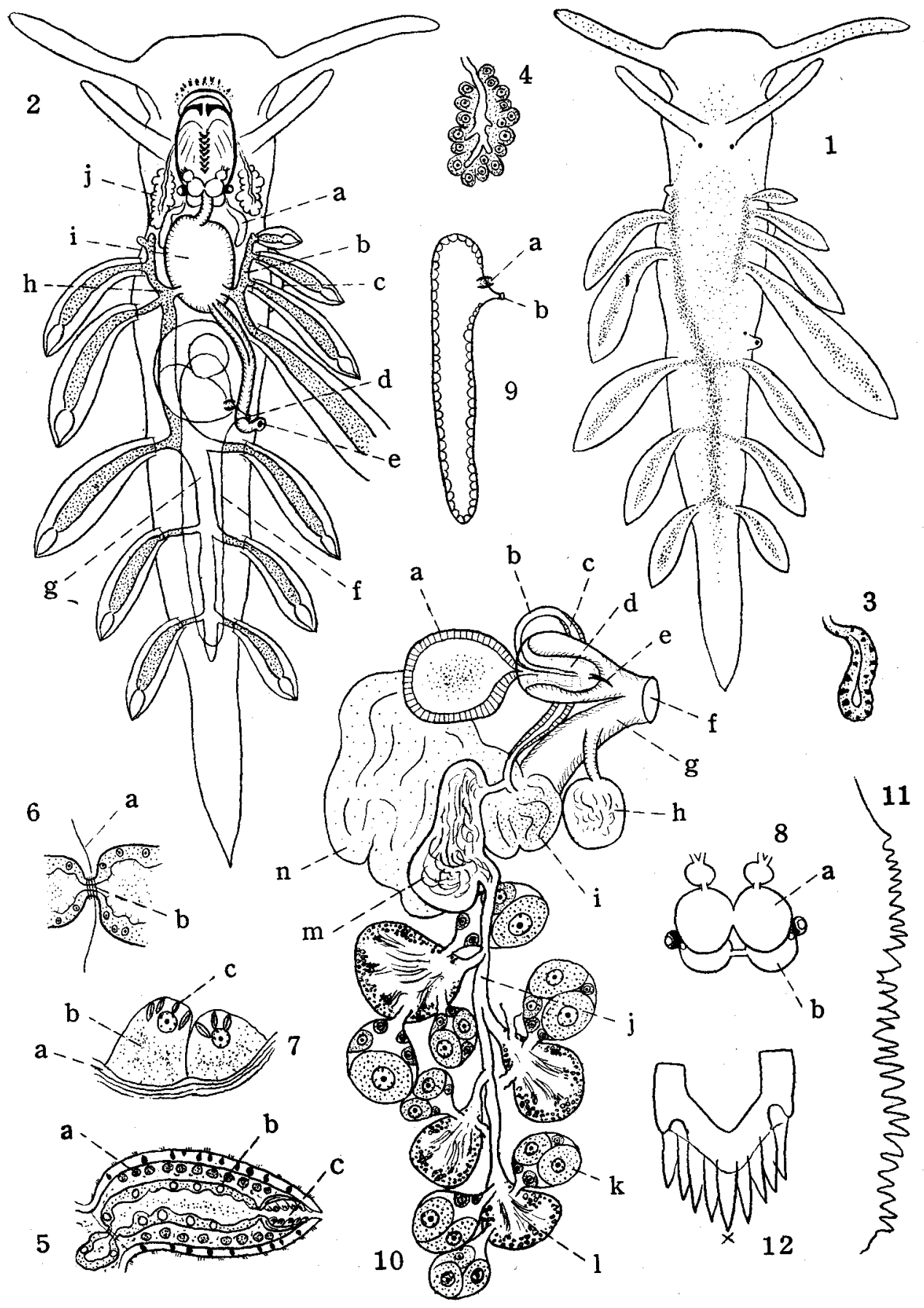

K. Baba: Anatomical Review of Subcuthona pallida Baba 